\title{
Effects of Polyherbal Tablet for Hypertensive Patients
}

\author{
Woro Rukmi Pratiwi*, Eti Nurwening Sholikhah, Dwi Aris Agung Nugrahaningsih, \\ Mia Munawaroh Yuniyanti, Mustofa, Setyo Purwono \\ Department of Pharmacology and Therapy, Faculty of Medicine, Public Health and Nursing, Universitas Gadjah \\ Mada, Yogyakarta, Indonesia
}

\begin{abstract}
Hypertension is a degenerative disease whose prevalence is high and continues to increase over time. Polyherbal tablet have long been used by Indonesian people for hypertension drugs containing garlic (Alium sativum), jelawe (Belericae fructus), temu ireng rhizomes (Curcumae aeruginosae) and kapulaga (Amomi fructus) extracts. This study aims to determine the effect of polyherbal tablet on hypertensive patients. The subjects of 29 hypertensive patients participated in a open-randomized-without comparisonstudy for 6 weeks. Subjects were divided into 3 groups, each subject received polyherbal tablet with a dose of 2x600 mg (group 1), 2x1200 mg (group 2) and 2x2400 mg (group 3). Blood pressure was monitored on D-0, D-3, D-5, D-7, W-2, W-3, W-4, W-5 and W-6. There was a significant decrease in systolic and diastolic blood pressure at the sixth week in all three treatment groups. The highest decrease in systolic blood pressure was in group 1 while diastolic blood pressure was in group 2 (-22.94 \pm 5.871 and $13.13 \pm 4.324$ respectively). The lowest reduction in systolic and diastolic blood pressure occurred in the third group ($15.07 \pm 3,519$ and $8.98 \pm 3,394$ respectively). This study suggests that polyherbal tablet contains garlic (Alii sativi), jelawe (Belericae Fructus), temu ireng rhizome (Curcumae aeruginosae) and cardamom (Amomi Fructus) can reduce blood pressure in patients with hypertension.
\end{abstract}

Keywords: Garlic; Belericae fructus; Curcumae aeruginosae; Amomi fructus; hypertension

\section{INTRODUCTION}

Hypertension is one of the global burdens of disease, with patients diagnosed with hypertension worldwide reaching 1 billion people in 2008 and it is estimated that it will continue to increase every year (WHO, 2013). Uncontrolled hypertension will cause several serious complications, namely myocardial infarction, stroke, renal failure and death (James et al., 2104). In addition to controlling risk factors such as obesity, physical inactivity and low salt diets, hypertension control strategies are focused on the administration of antihypertensive therapy (Rahimi et al., 2015)

One of several herbal medicines to treat hypertension in Indonesia is polyherbal tablet. Polyherbal tablet contain garlic (Alii sativi), jelawe (Belericae fructus), temu ireng (Curcumae aeruginosae) and cardamom (Amomi fructus) extracts. Garlic (Alii sativi) has been widely used to treat various cardiovascular disorders. The results showed that garlic can reduce the blood pressure of hypertensive patients better than placebo (Ried et al., 2016; Wang et al., 2015). Belericae fructus (Terminalia bellerica) has antioxidant and antihypertensive effects (Khan AU and Gilani AH, 2008; Chavan et al., 2010). Antioxidant activity is also possessed by Curcumae aeruginosae and

*Corresponding author : Woro Rukmi Pratiwi Email : wororukmi@ugm.ac.id
Amomi fructus (Choudhury et al., 2013; Nurcholis et al., 2015; Guo et al., 2008). Oxidative stress is the main mechanism in endothelial dysfunction and vascular damage, which has been known to play an important role in the pathogenesis of hypertension (Baradaran et al., 2014; Guzik and Touyz, 2017). Research has been conducted on the effectiveness of polyherbal tablet and the results show that polyherbal tablet a dose of $252 \mathrm{mg} / \mathrm{kgBB}$ (equivalent to the dose in humans) can reduce the blood pressure of mice in the hypertension model (Ngatidjan and Nugrahaningsih, 2016). So the purpose of this study is to determine the effect of polyherbal tablet in hypertensive patients.

\section{METHODOLOGY}

This study has received appropriate ethical approval (Number: KE/FK/0234/EC/2018) from the Medical and Health Research Ethics Commission of the Faculty of Medicine, Public Health and Nursing, Gadjah Mada University. The subjects of this study were hypertensive patients who had never been treated or who had been treated but had not taken medicine for 2 weeks or more with the inclusion criterias are adult, male and female, aged between 20-60 years; meet criteria for diagnosing hypertension stage 1 according to JNC 8 (TDS 140-159 or TDD 90-99 $\mathrm{mmHg}$ ); new or stage 1 hypertensive patients which within 14 days before recruitment do not 


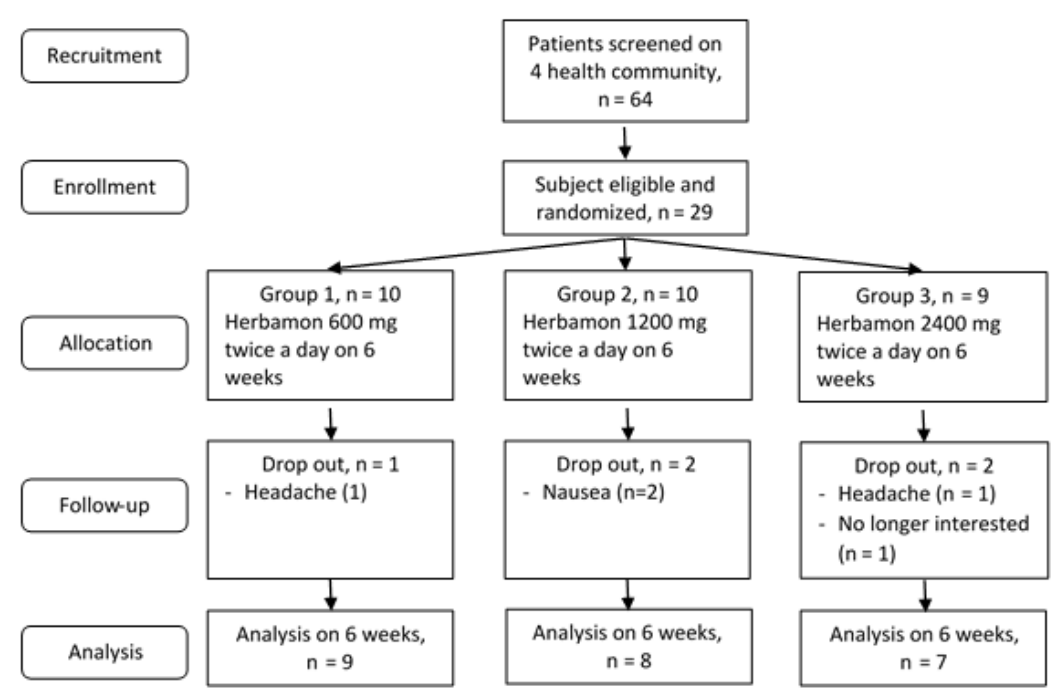

Figure 1. Trial flow chart

take antihypertensive drugs or herbs intended to reduce blood pressure; willing to take part in the study by signing an informed consent. Patients who are pregnant / lactating women, have a history of diabetes, a history of heart disease, liver function abnormalities (SGOT and / or SGPT> 3 times the upper limit of normal values), abnormal kidney function (urea and / or creatinine> 3 $\mathrm{mg} / \mathrm{dl})$, Polyherbal tablet hypersensitivity / intolerance was excluded.

This study is randomized, open-trial, without comparison. Subjects were divided into 3 groups, each subject received polyherbal tablet 2 times a day with polyherbal tablet doses of $2 \mathrm{x}$ 600mg (group 1), $2 \times 1200 \mathrm{mg}$ (group 2) and $2 \times$ 2400mg (group 3) for 6 weeks. Doses can be titrated according to blood pressure when monitoring measurements in D1, D3, D5, D7, W2, W3, W4, W5 and W6. The daily dose range of polyherbal tablet are 1200 - $4800 \mathrm{mg} / \mathrm{d}$. Polyherbal tablets preparations in tablet form were prepared by PT Marguna Tarulata APK Farma with $600 \mathrm{mg}$ strength. The subjects would get the tablets gradually along with blood pressure measurement. polyherbal tablet is taken twice with an interval of $12 \mathrm{~h}$. The tablets taken at the same time which is between 07.00-09.00 and 19.00-21.00, before or after meals. Subjects who meet the criteria to respond to therapy, they would receive a tablet of $7 \mathrm{~d}$ to week 6 . During the study, subjects were required to consult other drugs (including OTC) consumed to the researcher. Other drugs that can be consumed were drugs that do not affect the subject's blood pressure. All drugs consumed by the subjects were recorded and reported.
Examinations were carried out include vital sign examinations, basic physical examinations, ECG and laboratory examinations. Vital sign examination was carried out by paramedics in 9 times on D-0 (day 0), D-3, D-5, D-7, W-2, W-3, W-4, $\mathrm{W}-5$ and $\mathrm{W}-6$. Vital sign examination included examination of blood pressure, body temperature, pulse rate and respiratory rate. Blood pressure examination used a calibrated Standard adult size nylon aneroid sphygmomanometer. Measurements were performed at the position after the subject has sat quiet for at least 5 minutes in the chair and performed 2 measurements on the left arm that is parallel to the heart. The value obtained was the average of 2 measurements. The basic physical examination was carried out by the doctor, each subject was examined twice, at D0 and W-6. Physical examinations included examination of the cardiovascular, respiratory, gastrointestinal, dermatological, musculosceletal and nervous systems; examination of height and weight. Each subject received an ECG examination twice on D-0 and W-6. Laboratory tests included routine blood test, SGOT, SGPT, ureum and creatinine which were also carried out twice on D0 and $\mathrm{W}-6$.

\section{RESULT AND DISCUSSION}

The study was conducted in Plosokuning, Kayen, Kancilan, and Babadan DI Yogyakarta. Of the 64 people with hypertension during screening, 29 subjects met the inclusion criteria (Figure 1). Ten subjects were allocated in group 1 and group 2. Only 9 subjects is randomized into group 3 . One subject from group 1 dropped out (DO) at the beginning of taking the drug because of headache 


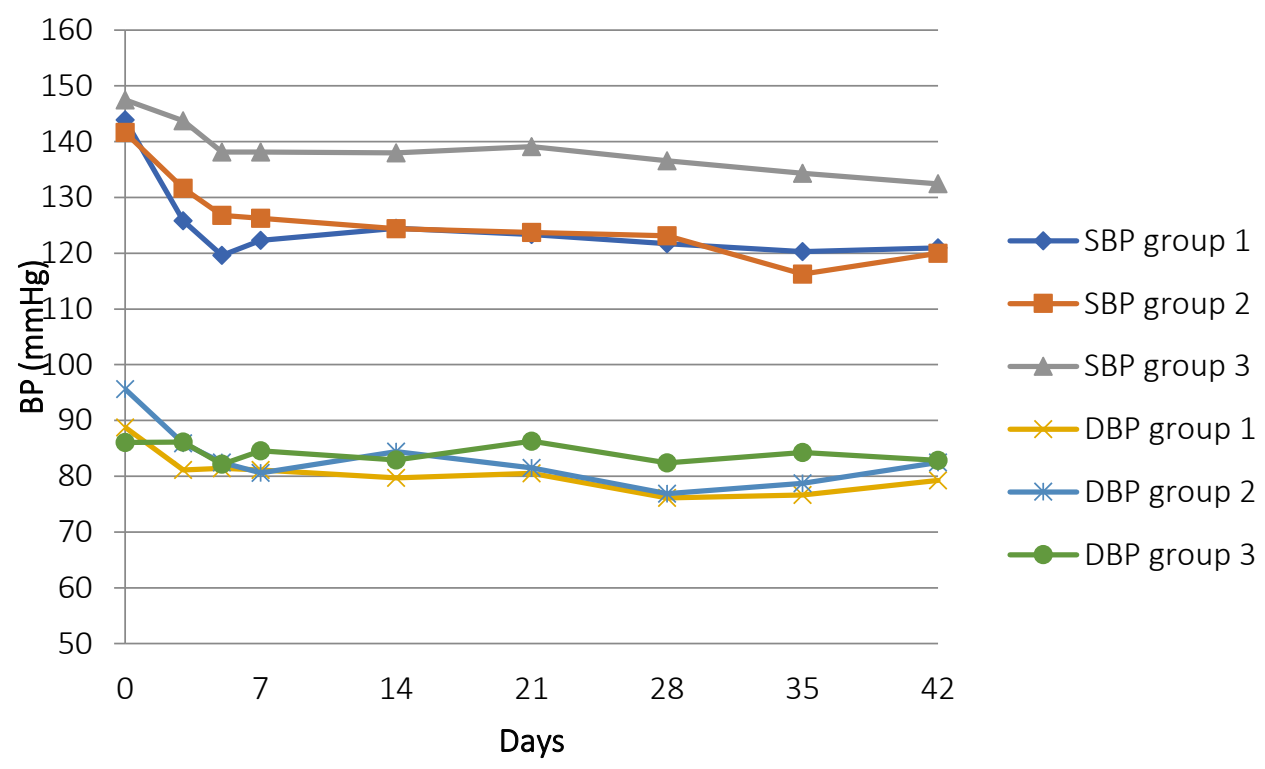

Figure 2. Effect polyherbal tablet on blood pressure by days.

complaint, 2 subjects from group 2 dropped out at the beginning of drug consumption and at day 5 because they complained of nausea, and 2 subjects from group 3 dropped out at the beginning of drug consumption and during the third week because they complained of nausea and decided not to continue the study. So that the number of subjects analyzed at the end of the study were 24 subjects.

Baseline characteristics did not differ significantly between treatment groups, including age, BMI and blood test parameters. Based on the BMI value of the participants, most of the participant was included in the overweight category with BMI average of $24.96 \pm 4.21$. The average of total cholesterol, LDL and HDL in groups 1 , grup 2 and grup 3 were $206.58 \pm 26.02$, $55.71 \pm 11.89$, and $136.75 \pm 23.99$ respectively (Table I). These data shows that most of the participant has dyslipidemia.

The mean blood pressure reduction from baseline compared to the end of the study (week 6) is presented in Table II. All groups showed a significant decrease in systolic blood pressure. The highest Systolic Blood Pressure decrease was seen in the group 1. Diastolic blood pressure decreased significantly only in the group 1 and 2 . The highest reduction in diastolic blood pressure was found in group 2. Figure 2 shows the mean blood pressure for each measurement. Eventhough the systolic blood pressure decreased in all three groups, systolic blood pressure in the third group did not reach the normal blood pressure value until the end of the study.
Our study showed that polyherbal tablet containing Alium sativum, Belericae fructus, Curcuma aeruginosa, dan Amomi fructus can reduce systolic blood pressure by an average of 20 $\mathrm{mmHg}$ and diastolic blood pressure by $10 \mathrm{mmHg}$. There was a significant decrease in systole blood pressure in the all groups and diastolic blood pressure in group 1 and 2 . The difference of mean systolic and diastolic blood pressure reduction were not statistically significant among the three groups ( $\mathrm{p}=.632$ and $\mathrm{p}=.231$ respectively). Grup 1 that received $2 \times 600 \mathrm{mg}$ tablet showed the highest decrease in systolic blood pressure. During the study, the subjects in the group 1 whom blood pressure fail to reach the normal value, the polyherbal dose was increased to a dose of 2 x1200 mg. This shows that the group 2 dose actually has a better blood pressure reduction effect than dose 1 . This result is in accordance with the results of preclinical study on hypertensive animal models (Ngatidjan and Nugrahaningsih, 2016). In preclinical study, blood pressure was the lowest at the group treated with the dose that equal to the dose used in group 2 of the present study.

Polyherbal tablet used in this study contains garlic (Alii sativi), jelawe (Belericae Fructus), temu ireng rhizome (Curcumae aeruginosae) and cardamom (Amomi Fructus) extracts. Several meta-analyzes showed that garlic can reduce blood pressure in patients with hypertension (Ried, 2014; Xiong et al., 2015). Effects of blood pressure reduction by garlic with a dose range of 240$2400 \mathrm{mg}$ can reduce systolic blood pressure by 
Table I. Baseline characteristics

\begin{tabular}{|c|c|c|c|c|}
\hline Characteristics & $\begin{array}{l}\text { All Subjects * } \\
(\mathrm{n}=24)\end{array}$ & Group $1(n=9)$ & Group $2(n=8)$ & Group $3(n=7)$ \\
\hline Gender (m/f) & $1 / 23$ & $0 / 9$ & $0 / 8$ & $1 / 6$ \\
\hline \multirow{2}{*}{$\begin{array}{l}\text { History of } \\
\text { smoking (n/\%) }\end{array}$} & $1 / 4$ & $0 / 0$ & $0 / 0$ & $1 / 14$ \\
\hline & mean $\pm S D$ (range) & & mean $\pm S D$ & \\
\hline Age (years) & $\begin{array}{c}51.50 \pm 6.56 \\
(39-60)\end{array}$ & $49.22 \pm 6.18$ & $51.63 \pm 6.55$ & $54.29 \pm 6.87$ \\
\hline BMI $\left(\mathrm{kg} / \mathrm{m}^{2}\right)$ & $\begin{array}{c}24.96 \pm 4.21(19.55- \\
32.70)\end{array}$ & $23.83 \pm 4.67$ & $25.49 \pm 3.39$ & $25.79 \pm 4.71$ \\
\hline $\mathrm{Hb}(\mathrm{g} / \mathrm{dL})$ & $\begin{array}{c}12.74 \pm 1.04(10.20- \\
14.70)\end{array}$ & $12.62 \pm .92$ & $13.14 \pm .81$ & $12.44 \pm 1.39$ \\
\hline $\operatorname{RBC}\left(10^{6} / \mu \mathrm{L}\right)$ & $\begin{array}{c}4.64 \pm .38 \\
(3.75-5.43)\end{array}$ & $4.48 \pm .35$ & $4.78 \pm .37$ & $4.67 \pm .39$ \\
\hline $\begin{array}{l}\text { Hematocrite } \\
(\%)\end{array}$ & $\begin{array}{c}39.44 \pm 2.74(35.70- \\
44.00)\end{array}$ & $39.07 \pm 3.12$ & $40.50 \pm 2.20$ & $38.70 \pm 2.81$ \\
\hline \multirow[t]{2}{*}{$\mathrm{WBC}(/ \mu \mathrm{L})$} & $\begin{array}{c}7238.33 \pm 1202.5 \\
(5230-10150)\end{array}$ & $7228.89 \pm 1252.1$ & $7438.75 \pm 1505.8$ & $7021.43 \pm 835.9$ \\
\hline & $293250 \pm 67242$ & $289333 \pm 68167$ & $269875 \pm 38394$ & $325000 \pm 86540$ \\
\hline Trombocyte & $(179000-466000)$ & & & \\
\hline $\begin{array}{l}(/ \mu L) \\
\operatorname{SGOT}(U / L)\end{array}$ & $\begin{array}{c}18.58 \pm 4.58 \\
(12-27)\end{array}$ & $17.33 \pm 4.95$ & $19.38 \pm 4.50$ & $19.29 \pm 4.50$ \\
\hline SGPT (U/L) & $\begin{array}{c}16.13 \pm 7.66 \\
(7-45)\end{array}$ & $16.00 \pm 11.31$ & $15.75 \pm 3.20$ & $16.71 \pm 6.45$ \\
\hline TC (mg/dL) & $\begin{array}{c}206.58 \pm 26.02 \\
281)\end{array}$ & $201.78 \pm 23.06$ & $208.13 \pm 20.56$ & $211.00 \pm 36.50$ \\
\hline TG (mg/dL) & $\begin{array}{c}116.92 \pm 47.88(72- \\
241)\end{array}$ & $102.33 \pm 24.76$ & $127.38 \pm 53.73$ & $123.71 \pm 63.92$ \\
\hline HDL (mg/dL) & $\begin{array}{c}55.71 \pm 11.89 \\
(35-79)\end{array}$ & $58.56 \pm 9.28$ & $54.38 \pm 16.92$ & $53.57 \pm 8.54$ \\
\hline LDL (mg/dL) & $\begin{array}{c}136.75 \pm 23.99(100- \\
197)\end{array}$ & $132.33 \pm 25.52$ & $138.00 \pm 17.28$ & $141.00 \pm 30.62$ \\
\hline Ureum (mg/dL) & $\begin{array}{l}25.53 \pm 9.25 \\
(14.0-50.5)\end{array}$ & $23.12 \pm 5.40$ & $29.29 \pm 14.53$ & $24.34 \pm 3.64$ \\
\hline $\begin{array}{l}\text { Creatinine } \\
(\mathrm{mg} / \mathrm{dL})\end{array}$ & $\begin{array}{c}.74 \pm .14 \\
(.47-1.00)\end{array}$ & $.67 \pm .11$ & $.78 \pm .15$ & $.80 \pm .11$ \\
\hline
\end{tabular}

Abbreviations: BMI, body mass index; f, female; Hb, hemoglobin; HDL, high-density lipoprotein; LDL, lowdensity lipoprotein; m, male; RBC, red blood cells count, SD, standard deviation; SGOT, serum glutamic oxaloacetic transaminase; SGPT, serum glutamic pyruvic transaminase; TC, total cholesterol; TG, triglycerides; WBC, white blood cells count.

* no significant differences between groups

$8.35 \mathrm{mmHg}$ and diastolic pressure by $6.1 \mathrm{mmHg}$ (Ried, 2014). The garlic active compound which is suggested to have antihypertensive effects are sallylcysteine, allicin, allyl methyl sulfide (AMS) and diallyl sulfide (DAS). The garlic antihypertensive action is suggested due to its antioxidant activity by trapping reactive oxygen species such as $\mathrm{O}_{2}^{-}$and $\mathrm{H}_{2} \mathrm{O}$; inhibiting the activity of NADPH oxidase; and increasing the activity of superoxide dismutase (potent antioxidant). Besides the hypotensive effect of garlic also through inhibiting of $\mathrm{Na}+$ channel activity, suppresing $\mathrm{NF} \kappa \mathrm{B}$ expression thereby reducing atherosclerosis, triggering the production of $\mathrm{H} 2 \mathrm{~S}$ which functions as a vasodilator, inhibiting ACE, and inhibiting Angiotensin IIinduced cell cycle production from vascular smooth muscle cells (Hosseini and Hosseinzadeh, 2015; Ried and Fakler, 2014; Shouk et al., 2014). Belericae fructus or jelawe is thought to have antihypertensive effects through inhibition of 
Table II. Mean changes of sitting blood pressure from baseline compared with the end of study

\begin{tabular}{lllll}
\hline Treatment & N & Mean change (SE) & 95\% CI & $p$-value \\
\hline Systolic blood pressure & & & & .004 \\
Polyherbal tablet 2x 600 mg & 9 & $-22.94(5.871)$ & $(-36.483,-9.406)$ & .011 \\
$\begin{array}{l}\text { Polyherbal tablet 2x1200 mg } \\
\text { Polyherbal tablet 2x2400 mg }\end{array}$ & 8 & $-21.63(6.279)$ & $(-36.473,-6.777)$ & .005 \\
Diastolic blood pressure & & $-15.07(3.519)$ & $(-23.683,-6.460)$ & \\
Polyherbal tablet 2x600 mg & 9 & $-9.56(3.648)$ & $(-17.968,-1.143)$ & .031 \\
Polyherbal tablet 2x1200 mg & 8 & $-13.13(4.324)$ & $(-23.349,-2.901)$ & .019 \\
Polyherbal tablet 2x2400 mg & 7 & $-8.98(3.394)$ & $(-11.520,5.092)$ & .380 \\
\hline
\end{tabular}

$\mathrm{Ca} 2+$ influx on calcium channels and through its antioxidant effects. Research conducted by Namphootiri et al (2011) showed that Belericae fructus has antioxidant activity and radical scavenging in DPPH, superoxide and hydroxy radical due to its gallic acid and ferulic acid content. Curcuma aeruginosa and Amomi fructus also have antioxidant effects (Nurcholis et al., 2015; Guo et al., 2008). Study conducted by Moon-ai et al (2012) of 15 Zingiberaceae plants showed that Curcuma aeruginosa had a significant superoxide dismutase activity. Whereas Amomi fructus has DPPH radical scavenging activity and ferric reducing antioxidant power (FRAP) which can scavenging free radical and reduces prooxidants (Guo et al., 2008). Oxidative stress is the main mechanism in endothelial dysfunction and impaired vascular relaxation, which has been known to play an important role in the pathogenesis of hypertension. So that antioxidants administration is hypothesized to function as a vascular protector (Siti et al., 2015).

The treatment with highest dose of the poliherbal(Polyherbal tablet $2 \times 2400 \mathrm{mg}$ ) showed the lowest reduction in blood pressure. This result is also in accordance with studies in rat, that showed that at the highest doses the decrease of the blood pressure was not better than lower dose. It might be caused by the antioxidant effect of the compound in the polyherbal. In the high dose, the antioxidant can be converted into prooxidant and loss it protective effect (Bouayed and Bohn, 2010; Suru and Ugwu 2015).

\section{CONCLUSION}

The polyherbal tablet contains garlic (Alii sativi), jelawe (Belericae Fructus), temu ireng rhizome (Curcumae aeruginosae) and cardamom (Amomi Fructus) can reduce blood pressure in patients with hypertension.

\section{ACKNOWLEDGEMENT}

We thank to all patients, village head and health cadres for their involvement and helping in this study. This research was funded by Ministry of Research, Technology and Higher Education grant, Republic of Indonesia. Thank you to Prof. Dr. Mae Sri Hartati W, Apt, M.Si and Prof. dr. Ngatidjan, MSc, SpFK for her support for this research. Polyherbal tablet procurement is provided by PT Marguna Tarulata APK Farma which is not involved in the design preparation, data collection, analysis and research publication.

\section{REFERENCES}

Baradaran A, Nasri H, Kopaei MR., 2014, 'Oxidative stress and hypertension: Possibility of hypertension therapy with antioxidants', J res med sci. 19(4), 358-367.

Bouayed J and Bohn T., 2010, 'Exogenous antioxidants-double edged swords in cellular redox state: health beneficial effects at physiologic doses versus deleterious effects at high doses', Oxid Med Cell Longev. 3(4), 228-237.

Chavan LV, Anita P, Naresh P., 2010, 'Antioxidant availability of beheda (terminalia bellerica (roxb.)) in relation to its medicinal uses'. PHCOG J. 2(10), 338-343.

Choudhury, D., Ghosal, M., Das, A.P., et al., 2013, 'Development of single node cutting propagation techniques and evaluation of antioxidant activity of Curcuma aeruginosa, Roxburgh rihome', IJPPS. 5(2), 227-234.

Guo DJ, Cheng HL, Chan SW, et al., 2008, 'Antioxidative Activities and The Total Phenolic Contents of Tonic Chinese Medicinal Herbs', Inflammopharmacology. 16, 201-207.

Guzik TJ and Touyz RM, 2017, 'Oxidative Stress, Inflammation and Vascular Aging in Hypertension', Hypertension. 1-9.

Hosseini A and Hosseinzadeh HA, 2015, 'Review on the effects of Allium sativum (garlic) in metabolic syndrome', J Endocrinol Invest.

James PA, Oparil S, Carter BL et al., 2014, 'EvidenceBased Guideline for The Management of High Blood Pressure in Adults: Report From 
The Panel Members Appointed to The Eighth Joint National Committee (JNC 8)', JAMA. 311(5), 507-520.

Khan AU and Gilani AH., 2012, 'Pharmacodynamic evaluation of Terminalia bellerica for its antihypertensive effect', Journal of Food and Drug Analysis. 16(3), 6-14.

Moon-ai W, Niyomploy P, Boonsombat R et al. 2012, 'A superoxide dismutase purified from the rhizome of Curcuma aeruginosa roxb. as inhibitor of nitric oxide production in the macrophage-like RAW 264.7 cell line', Appl Biochem Biotechnol. 166, 2138-2155.

Nampoothiri SV, Raj SSB, Prathapan A, et al., 2011, 'In vitro antioxidant activities of the methanol extract and its different solvent fractions obtained from the fruit pericarp of Terminalia bellerica'. Natural Product Research. 25(3), 277-287.

Ngatidjan, Nugrahaningsih DAA., 2016, 'Pengembangan Herbamon sebagai fitofarmaka untuk hipertensi melalui studi praklinik dan klinik (tahun 1)', Laporan Penelitian PUPT-DRPM-Kemenristekdikti RI. Yogyakarta.

Nurcholis W, Khumaida N, Syukur M, et al., 2015, 'Phytochemical screening, antioxidant and cytotoxic activities in extracts of different rhizome parts from curcuma aeruginosa roxb Int.' J. Res. Ayurveda Pharm. 6, 634-637.

Rahimi K, Emdin CA, MacMahon S., 2015, 'The Epidemiology of Blood Pressure and Its Worldwide Management', Circulation Research. 925-936.

Ried K and Fakler P., 2014, 'Potential of garlic (Allium sativum) in lowering high blood pressure: mechanisms of action and clinical relevance', Integrated Blood Pressure Control. 7, 71-82.

Ried K, Travica N, Sali A., 2016, 'The Effect of Aged Garlic Extract on Blood Pressure and Other Cardiovascular Risk Factors in Uncontrolled Hypertensives: The AGE at Heart Trial' , Integrated Blood Pressure Control. 9, 9-21.

Ried K., 2014, 'Garlic lower blood pressure in hypertensive individuals, regulates serum cholesterol, and stimulates immunity: an updated meta-analysis and review', The journal of nutrition. 1-8.

Shouk R, Abdou A, Shetty K, et al., 2014, 'Mechanisms underlying the antihypertensive effects of garlic bioactives', Nutrition research. 34, 106-115.

Siti HN, Kamisah Y, Kamsiah J., 2015, 'The Role of Oxidative Stress, Antioxidants and Vascular Inflammation in Cardiovascular Disease (A Review)', Vascular Pharmacology, 71, 40-56.

Suru SM and Ugwu CE., 2015, 'Comparative assessment of onion and garlic extracts on endogenous hepatic and renal antioxidant status in rat', J Basic Clin Physiol Pharmacol. 26(4), 347-354.

Wang HP, Yang J, Qin LQ, et al., 2015, 'Effect of garlic on blood pressure: a meta-analysis', The Journal of Clinical Hypertension. 17(3):223-231.

WHO., 2013, 'A Global Brief on Hypertension: Silent Killer', Global Public Health Crisis. Geneva.

Xiong XJ, Wang PQ, Li SJ et al., 2015, 'Garlic for hypertension: a systematic review and meta-analysis of randomized controlled trials', Phytomedicine. 22, 52-361. 